\title{
The Role of Culture in the Experiences of Pre-Service Teachers in Using IsiXhosa to Teach Science Subjects in Grade 4-9
}

\author{
Nozuko Zukiswa Gxekwa, Nomsa Satyo \\ Department of African Languages, IsiXhosa, Faculty of Humanities and Social Science, University of Fort Hare, East London, South Africa
}

Email address:

ngxekwa@ufh.ac.za (N. Z. Gxekwa),nsatyo@ufh.ac.za (N. Satyo)

\section{To cite this article:}

Nozuko Zukiswa Gxekwa, Nomsa Satyo. The Role of Culture in the Experiences of Pre-Service Teachers in Using IsiXhosa to Teach Science Subjects in Grade 4-9. International Journal of Education, Culture and Society. Vol. 2, No. 6, 2017, pp. 158-164. doi: $10.11648 /$ j.ijecs.20170206.11

Received: February 14, 2017; Accepted: February 23, 2017; Published: November 24, 2017

\begin{abstract}
There are language limitations that can prevent certain concepts from being part of a culture. In other words, there is an intricate relationship between culture and language that cannot be denied in any context including science education at primary school level. The purpose of this study is to identify and offer solutions to the main challenges that are experienced by pre-service teachers in using isiXhosa as a medium of instruction in teaching scientific subjects such as Biology, Geography and Life Orientation. The theoretical frameworks used in this study drew from the theory of cognitive dissonance and cultural linguistics. A purposive sample of thirteen pre-service teachers who were majoring in these subjects was used. Data was collected during teaching practice, using classroom observations and one-on-one interviews, and it was inductively analysed into four themes reflecting cultural experiences that do not translate directly between cultures, use of "taboo words", dialects and "ukuhlonipha" a form of respect for elders, married women and initiates in isiXhosa.
\end{abstract}

Keywords: Culture Specific, Cognitive Dissonance, Ukuhlonipha, Science Subjects, Dialects, Sensitive and Taboo Words, Pre-service Teachers

\section{Introduction}

Much of the research on language in science teaching has focused on ways of supporting learners (and teachers) in multilingual classrooms where English is the language of learning and teaching (LoLT) (see for instance Desai [5]; Msimanga \& Lelliott [24]. IsiXhosa is one of the languages that are used LoLT in schools in South Africa at some primary and secondary schools in South Africa. This is done with the agreement of the School Governing Body and School Management Team in cases where the majority of learners are isiXhosa $1^{\text {st }}$ language speakers.

Research into pedagogic issues arising from science classrooms where isiXhosa is the LoLT has focused on the attitudes of various stakeholders (learners, teachers, parents) to the use of the indigenous language as LoLT.

Interestingly, the bulk of current research in this area is focused on the use of indigenous languages in teaching science and engineering at tertiary level; Madiba, [19]. A second body of research on the use of indigenous languages in science teaching has focused on the linguistic issues.

Accepting that science discourse has its own genre; Lemke [17], the classic work of Dlodlo [7] shows that students of science whose mother tongue has not been used in scientific discourse have "very special additional difficulties of cognition and understanding", because they cannot "appeal to translation into the mother tongue for resolution of doubt or dissipation of ignorance". Nomlomo and Mbekwa's [20] work is limited to linguistic issues of science terminology and lack of training in using indigenous languages as LoLT. In contrast, this paper explores the under-researched areas of the role of culture in using an indigenous language; specifically isiXhosa to teach science subjects at primary school level.

The purpose of this study is to identify and offer solutions to the main challenges that are experienced by pre-service teachers in using isiXhosa as a medium of instruction in teaching scientific subjects such as Biology, Geography and 
Life Orientation. The study addresses the following questions: (i) what are the main challenges that are experienced when using isiXhosa as medium of instruction when teaching science subjects at primary school level? and (ii) how do pre-service teachers overcome these challenges? Which approaches do they use to make sure their teaching progresses without hindrance? Lastly is to add to literature on challenges of using isiXhosa as LoLT for subjects such as Life Orientation, Biology and Geography and also to provide strategies on how to use isiXhosa effectively in teaching these scientific subjects.

\section{Theoretical and Conceptual Framework of Research}

Since this study examines the nexus between language and culture, an appropriate practical framework is the cultural linguistic theory because it studies the relationship between language and culture. Sapir [30] states that socio-cultural linguists, especially in the United States, take an interdisciplinary approach to the study of language and the social and cultural functions of language use. Language and culture cannot be separated because culture is displayed in ideas through a language. It can be difficult for teachers to teach scientific subjects as some of the concepts might be new or not available in their culture, or concepts are available in their culture but there is no apparent language to express these. These tensions can cause anxiety. Thus, cognitive dissonance theory is also used in this study. Festinger's [9] theory of cognitive dissonance focuses on how humans strive for internal consistency. When inconsistency (dissonance) is experienced, individuals tend to become psychologically uncomfortable and are motivated to attempt to reduce this dissonance, as well as actively avoiding situations and information is likely to increase it.

Experiences of cognitive dissonance are relevant to decision making and problem solving, as there is, frequently, competition between choices or solutions. Having experienced cultural challenges in their classes, participants in the studying had to devise problem solving strategies.

\section{Literature Review}

Desai [5] quoted Alexander in her paper on promoting African Languages stating that he propagated the maxim that languages develop through use, particularly in high domains such as education.

The Language Policy of South Africa promotes the use of African Languages as Language of Learning and Teaching or medium of instruction. UNESCO [33] promotes mother tongue-based bilingual or multilingual approaches in education - an important factor for inclusion and quality in education. Mother-tongue instruction refers to the use of learners' mother tongue as medium of instruction. UNESCO [33] describes the term "mother tongue" as follows: The language that one has learnt first; the language one identifies with or is identified as a native speaker of by others; the language one knows best and the languages one uses most. Prah [28] argues that the language of instruction becomes the language of educational formation in any society and it is also a language of power. He further states that this is a language in which production and reproduction of knowledge is taught.

Language and culture cannot be separated, because culture is displayed in ideas as well, and that means people have to express these ideas using a language and certain cultures that do not exist in other ones or different social practices require "special language" for some concepts. Culture is assimilated through language, as it unlocks meaning and heritage. This paper strives to highlight cultural challenges of using isiXhosa as LoLT in teaching scientific subjects that this paper focuses on and how to address them for isiXhosa to be used successfully and be developed. Prah [28] comments:

Countries such as Tanzania ensure that Kiswahili, an African Language, dominates as a language of instruction, because cultural freedom and African emancipation cannot be cultivated, expanded or developed where the Language of Instruction (LOI) is different from the languages or language that people normally speak in their everyday lives. Where LOI is different from languages of mass society, those who work in the LOI, foreign from the language of the masses, become culturally removed and alienated from the masses.

Lastly, there are many incorrect translations of terminologies from English to isiXhosa used in the classroom to try to fill the gap between culture and language in education. These incorrect translations are caused by different cultural backgrounds, differences in expressive meaning, religions and beliefs; Jadezweni \& MfazweMojapelo [15].

\section{Research Design}

The study adopted a qualitative approach (QA). The QA was suitable for this study for reporting observed learning environments and lesson activities to answer the research questions.

\section{Data Collection}

Data in this study was collected during teaching practice using non-participant observations and one-on-one semistructured interviews. Teaching practice was the context for the study because the participants used isiXhosa to teach scientific subjects used in this paper. The subjects of the study were Bachelor of Education (B. Ed.) IV isiXhosa speaking pre-service teachers.

\subsection{Non-Participant Observation}

The researcher went to observe pre-service teachers in their lessons and played the role of non-participant-observer while gathering observational data. The researcher observed the language used by pre-service teachers when using isiXhosa while teaching science subjects and took noted 
while observing. The observations enabled the researcher to make some significant conclusions on how the pre-service teachers were using language while teaching their classes. Non-participant observation is often used in tangent with other data collection methods, and can offer a more "nuanced and dynamic" appreciation of situations that cannot be as easily captured through other methods; Liu \& Maitlis [18]

\subsection{Individual Semi-Structured Interviews}

The decision to interview implies a value on personal language as data; McMillan \& Schumacher [35]. Face-toface interviewing may be appropriate where depth of meaning is important and the research is primarily focused in gaining insight and understanding; Gillham [11]; Ritchie \&Lewis [29]. One-on-one semi-structured interviews allow for flexibility, probing for details and asking for clarification where necessary. Gomm [12] describes the cooperative nature of the interview as a "fact-producing interaction". The interview took place just after the pre-service teachers taught their lessons. The interviews also played a role as a reflection tool for lessons. The length of the interviews depended on the practices that occur during the lesson, and the focus was on the usage of language.

\section{Sampling}

A purposive sample was used of thirteen pre-service teachers who were in their final year of BEd studies and majoring in these science subjects. Out of twenty seven isiXhosa speaking final year student; only thirteen wanted to take part in the study. These students at a University of Technology were isiXhosa speakers were placed in isiXhosa medium schools teaching scientific subjects in isiXhosa. Purposive sampling is used to select participants considered to be information-rich. The purposive sampling technique is a type of non-probability sampling that is most effective when one needs to study a certain cultural domain with knowledgeable experts, and choosing the purposive sample is fundamental to the quality of data gathered; thus, reliability and competence of the informant must be ensured; Mouton [23].

\section{Data Analysis}

Data was inductively analysed into four themes which emerged from the data as inductive analysis; Glaser \& Strauss [13]. Inductive content analysis is a qualitative method of content analysis that researchers use to develop theory and identify themes by studying documents, recordings and other printed and verbal material. As the name implies, inductive content analysis relies on inductive reasoning in which themes emerge from the raw data through repeated examination and comparison.

\section{The Research Findings and Discussion}

Pre-service teachers who participated in the study also indicated that their cultural beliefs at times caused dissonances when using isiXhosa as LoLT when teaching Social, Life and Natural Sciences, i.e. Geography, Life Orientation and Biology. The following are the themes that emerged as challenges from the responses:

1. Culture-specific terms;

2. Sensitive or taboo words;

3. Ukuhlonipha language (respect);

4. Dialectically diverse groups of learners with different cultures.

For the analysis of results in this study, two theoretical and conceptual frameworks (cultural linguistic theory and cognitive dissonance) discussed earlier were utilised

\subsection{Culture-Specific Terms}

Newmark [25] points out five areas (with sub-categories in each) that cultural items may come from, namely: (1) ecology (flora, fauna, winds etc.), (2) material culture (artefacts, food, clothes, houses and towns, transport), (3) social culture (work and leisure), (4) organizations, customs, ideas (political, social, legal, religious or artistic), and (5) gestures and habits. Gambier also refers to such concepts as 'culture-specific references' and asserts that they connote different aspects of life; he states that:

Culture-specific references connoting different aspects of everyday life such as education, politics, history, art, institutions, legal systems, units of measurement, place names, foods and drinks, sports and national pastimes, as experienced in different countries and nations of the world. These culture-specific concepts in the source language word may express a concept which is totally unknown in the target culture; Gambier [10].

Baker [1] refers to such cultural words and concedes that the SL words may express a concept which is totally unknown in the target culture. She points out that the concept in question may be "abstract or concrete and may relate to a religious belief, a social custom, or even a type of food."

Below are examples that were observed to illustrate culture-specific terms in the classroom.

\section{Examples from the pre-service teachers}

\section{GEOGRAPHY}

Student X was teaching a lesson about "the land", and she was explaining about the sky and grass. To explain the colours she said:

Ingca igreen. (igreen) meaning it's green

Isibhakabhaka siblue. (iblue) meaning it's blue

She preferred to use a mix of English and isiXhosa, but the simple way to show the difference between blue and green is by saying:

Green - luhlaza okwengca (like grass)

Blue - luhlaza okwesibhakabhaka (like the sky)

Pre-service teachers decided to code-switch or use euphemisms as problem-solving strategies for their challenges. In some cultures (e.g., the Xhosa culture), the colour vocabulary is limited and the name of a common object whose colour is a prominent attribute is sometimes used when referring to a colour name. For example, in 
isiXhosa the word for "blue" and "green" is the same, so to more accurately describe the colour of something that is blue or green an object is added to the word such as "like the sky" or "like the grass".

\section{$B I O L O G Y$}

Student $\mathrm{Y}$ did not want to use the term ubunkunzi bentyatyambo (referring to the male part for a plant) as it was in a document provided to him by the mentor teacher. When interviewed, he said the term "inkunzi" cannot be used to refer to a flower (inkunzi refers to animals, and inkunzi is a valued creature by amaXhosa, thus it cannot be used to refer to plants).

\section{LIFE ORIENTATION}

Student Q was referring to Schizophrenia as amafufunyana/ukuthwasa.

Ukuthwasa refers to a process of graduating as a traditional healer while amafufunyana refers to being possessed by demons. The student used these terms to try and explain a Schizophrenic person. Niehaus [26] explains below that:

Amafufunyana' and 'ukuthwasa' are two culture-specific descriptive terms. Xhosa traditional healers explain that the terms representing aberrant behavioral and psychological phenomena are often used incorrectly as equivalents of Schizophrenia.

Student $\mathrm{T}$ referred to noctambulism as ukuthwetyulwa and hallucinations as ukumpola.

Translating many illnesses or explaining them might be difficult in isiXhosa. There is quite a few that the researcher has come across such as "noctambulism" which is a "sleep walking disease" that is explained as "ukuthwetyulwa" especially if a sleepwalking person walks out particularly near water. "Ukuthwetyulwa" is a process of being called by your ancestors in the river as one of the steps to becoming a traditional healer and has nothing to do with "sleep walking".

Another is Hallucinations which is often explained as "ukumpola", especially for old women as they are believed to be witches. "Ukumpola" is a term used to refer to someone revealing all their dirty or evil secrets before he/she dies. This is what occurs when the concept is translated incorrectly - the meaning is lost, and the outcome of the lesson is not effective.

Shuttleworth and Cowie; [31] argue that cultural translation is a term used to refer to those types of translation that act as a tool for cross-cultural or anthropological research.

They believe that cultural translation is sensitive to cultural and linguistic factors and takes different forms; and such sensitivity might take the form either of presenting Target Language (TL) recipients with a transparent text which informs them about elements of the source culture, or of finding target items which may, in some way, be considered to be culturally "equivalent" to the Source Language (SL) items they are translating. Larson [16] adds that there may also be both "technical and non-technical" vocabulary to talk about the same thing within a given society. Therefore, if the SL text originates from a highly technical society it may be much more difficult to translate it into the language of a nontechnical society. However, in the case of similar cultures, the conditions are not the same.

\subsection{Sensitive or Taboo Words}

Pre-service teachers highlighted that it is sometimes difficult for them to teach scientific learning areas because they feel that some of the terms are sensitive or sound rude for use for their learners. They also mentioned that sometimes, these terms are used in the community but by illiterate people. They often code-switch or use euphemisms to refer to these concepts, and this can confuse learners. What is taboo? Taboo is a cultural or religious custom that forbids people to do, touch, use or talk about a certain things. There is no language without taboo words (dirty words) in the world. Some expressions that are considered as taboo may elicit embarrassment or offence to people in one language or may be used naturally by people in other languages. Ellis [8] writes that a taboo, speaking roughly, simply indicates something that is "not done." The reason why it is not done may be, and often is, unknown to those who observe the taboo.

\section{Examples from pre-service teachers}

\section{LIFE ORIENTATION}

Student $\mathrm{Z}$ in the study was going to teach sexual transmitted diseases, HIV/AIDS. She informed the researchers that she needed to consult with the isiXhosa lecturer asking for assistance in translating the concepts. Furthermore, that there was a document available with some terms, but she could not use them because they sounded too rude or sensitive for the learners. She used euphemisms to resolve her tension and anxiety. She referred to HIV/AIDS as "amagama amathathu" meaning three words. The meaning of these terms is now lost as AIDS does not have three words, and the word does not explain the illness either. Ellis [8] states that one of the common causes of misinterpretation is that many African languages use metaphors, allusions and euphemisms, especially when dealing with illness. Mchunu [21] agrees with this referring to Zulu culture. He states that:

It is against this Zulu cultural taboo around the topic of sex that the present day scourge of HIV/AIDS must be seen. It can be assumed that HIV/AIDS has burgeoned under these strict codes of silence or taboo. Any educational program regarding AIDS will have to take into account these strong cultural taboos and find ways to retain them while yet loosening their hold so as to allow for healing and education.

Student $\mathrm{Z}$ again used the following phrase "ukuhamba ulala" to translate "sleeping around". The student was explaining unprotected sex as one of the ways in which one gets infected with HIV/AIDS.

She later stipulated that she could not use "ukulalana or ukwabelana ngesondo" as these two terms sounded harsh, rude and taboo for the kids. However, "ukuhamba ulala" does not mean having sex but means sleeping literally in different places or households.

BIOLOGY

The following are some of the concepts which the students 
did not want to use, and they ended up forming up their own or using euphemism:

1. Diarrhoea- urhudo/ isifo sotyatyazo (sensitive because it imitates the noise of diarrhoea). Students prefer the term: isisu esihambisayo (running tummy) - this can confuse learners as it is a direct translation.

2. Private parts- (male and female); they did not even want to say these words as there were lots of them and all were rude) (sensitive). She preferred to use: amalungu angezantsi (lower organs). They also used all kinds of unrelated words like igusha (sheep) or inkomo (cow) for a female sexual organ. They also used the term Umbhobho for the male sexual organ. Umbhobho refers to a pipe.

3. Syphillis - Isifo sangaphantsi (sensitive, because its literal meaning is a disease you have on your private parts). They used the term ihashe elimhlophe (white horse) - meaning was lost because learners now conceptualized the term to refer to a horse.

4. Condom- Isikhuseli sokulalana (sensitive), and they used the term ikhondomu (borrowed) or idyasi lomkhwenyane (groom's jacket) - meaning is lost to the latter as learners can literally assumes it is a jacket.

5. Pregnant- umithi (sensitive); they used the terms ukhulelwe (has gone heavy) unzima (she is heavy).

6. Infertile- Idlolo (sensitive), and used the term ukungazali (cannot give birth).

7. Placenta- umgcantsi (sensitive) and used the terms inwebu, ekhusela, usana (phrase) (mucous that protects the baby).

Students who participated in this study felt that it is easy to use these terms in English than isiXhosa, emphasizing that they do not sound rude in English. Second language speakers commonly acknowledge that taboo terms can be uttered with greater ease in their second language (L2) than in their first language (L1).

\subsection{Ukuhlonipha (Respect)}

Carton [3] explains that ukuhlonipha, a custom of deference, male and female youths and married women avoided male elders as means of respect and homage. AmaXhosa use ukuhlonipha in many different areas of life. For example, the initiates (abakhwetha) and married women use ukuhlonipha.

Examples from pre-service teachers

\section{GEOGRAPHY}

Student R teaching Social Sciences (Geography) who is a married woman had a problem. The lesson was about the rivers of South Africa, and a river is "umlambo". She could not say this term and kept on saying i-river because her husband's clan name is "Umlambo". Linguistically, isihlonipha sabafazi involves the avoidance, and so replacement of, certain phonemes occurring in the names of a women's male relatives, as well as female relatives who have a sort of honorary male status, like the mother-in-law. The non-linguistic applications extend to style of dress, posture and other customs, such as those relating to umakoti and ukuhota (See Bongela, [2]. According to Mchunu [21], the bride avoids addressing her parents-in-law directly, avoids looking them directly in the face and even when referring to them, she uses a particular hlonipha vocabulary.

\subsection{Dialects in the Classrooms}

One of the most talked about issues in language is whether or not to use the learner's non-standard variety in the classroom. Standardised language is often valued as being more logical and precise by public than non-standardised dialects. Non-standardised dialects are linguistically valid for the purpose of communication but socially and educationally, they are given low status (Spofana, [32]. This makes the status of non-standardised dialects in education very low, yet the third specific outcome of the Language, Literacy and Communication (LCC) learning area of 2005 requires learners to respond to aesthetic, affective, cultural and societal values of the text. One of the challenges the respondents of the study had was that learners pronounced words differently and use different concepts to refer to the same term because of their geographical regions. Diaz [6] suggests that schools should use and affirm culture and language as a foundation for learners' academic success rather than trying to erase culture and language. Thus, educators who deal with dialectically diverse groups of learners should know something about dialects of their learners so they could be in a position to communicate with their learners.

\section{Examples from pre-service teachers}

BIOLOGY

Student $\mathrm{X}$ experienced a problem with the following terms:

1. Chicken- inkuku/inkukhu;

2. Lizard-icikilishe/icilikishe; and

3. Skull- ukhakayi/ukhakhayi.

The above terms were confusing as learners in the classroom were pronouncing them differently; this created some dissonance to the teacher as learners were making a big issue out of this difference and wanting answers as to what is causing the differences.

Student Q was teaching on uses of water, and the learner gave an answer "siyawanatha mfundisi"; the teacher did not know the word "ukunatha", which means to drink in isiHlubi (a dialect of isiXhosa). This caused anxiety to the learner and the teacher as the learners made fun of the situation.

\section{Conclusion}

According to the Life Orientation Curriculum and Assessment Policy Statement (CAPS) (DBE, [4], teachers must address a curriculum topic entitled 'Development of the Self in Society'. This topic must be addressed in term two, week 1 to 3 . Three themes must be handled, the themes is Sexuality: attitudes, values and behaviour. Research has attested that this topic has been neglected in classroom curriculum practice due to not just a lack of pedagogical content knowledge, but to deep seated convictions and the 
belief systems of some educators (Moletsane, [22]. The voices of participants in this study need to be heard because it felt that they were not equipped enough in using African languages to teach scientific subjects. They had to come up with strategies that they are confident enough to use such as coining of terms or code-switching and visual aids to enhance their teaching. Cultural constraints have denied teachers the opportunity of conducting their situational analysis of sex education in Life Orientation content knowledge and pedagogy, of developing their teaching guides and lesson plans together, of sharing experiences and supporting one another and of reflecting (Nkoane [27]. The major barriers to sex education are cultural, and a lack of training, particularly teacher training in sex education. It is very important to note the challenges expressed by participants in this study as these cause anxiety to their teaching and learning. It is clear that one cannot separate language and culture because all findings highlight cognitive dissonance.

\section{Recommendations}

Sensitive and taboo words

Lessons can be drawn up to guide the teacher with regard to sex education through reflection and as such, breaking the silence reported by the researcher. This means in teacher training, students should be made aware of the fact that some words sound rude or taboo but should be used to clarify the content. For example, syphilis - Isifo sangaphantsi (sensitive, because its literal meaning is a disease you have on your private parts), s/he prefers ihashe elimhlophe (white horse) meaning lost because learners are now conceptualizing the term to refer to a horse.

Culture specific terms

It is very vital to also take note of culture-specific terms and how they can affect classrooms and cause anxiety in preservice teachers. Venuti [34] believes that viability of a translation is established by its relationship to the cultural and social conditions under which the translation is produced and read.

Spofana [32] states that dialects are part of teaching and learning and that there is a link between language and identity. Therefore, it is essential for educators to take into account that learners have a right to their own identity.

This means that educators who deal with dialectically diverse groups of learners should know something about dialects of their learners to avoid anxiety that can occur because of dialects in the classroom such as terms that are not spelled and pronounced the same or use of different terms to denote the same concepts

Culture-specific terms

Translation by cultural substitution: this strategy involves replacing a culturally-specific cite with one of the different meanings but similar impact in the translated text. This strategy gives the reader a concept which they can identify, understand, familiar and appealing to them. Also, translation using a loan word or loan word plus explanation - This strategy particularly deals with culture-specific items and modern concepts. This strategy is very useful when the translator deals with concepts that are wide and new to the target audience, culture-specific terms and proper names of diseases or medicines that are widely known in English names.

\section{Dialects}

Dialects can be used in class for communication or expressive purposes and if not, it does very little to help the learners to meet the demands of their own day-to-day real life communication situation (Gxilishe, [14]).

Dialects

Dialects in the classrooms as part of departure, nonstandardized dialects in isiXhosa could be accommodated in the classroom. This does not mean they will be used as medium of instruction or languages of learning and teaching, but will be used for communication. Learners could be encouraged to see how dialect study merges with Social Sciences. Dialect study, for instance, can be viewed from the perspective of Geography or History. In a History lesson, for instance, groups of learners may carry an independent research to determine the contributions of particular various Xhosa groups to a location or research about different Xhosa dialects. The Department of Education should also commit itself to developing dialect awareness programme.

\section{Ukuhlonipha}

Last but not least, the study highlighted ukuhlonipha (literally meaning respect generally as the act of avoidance. Teacher training should emphasise the disadvantages of this avoidance in the classroom and motivate the use of terms in the context of a classroom, especially for communication purposes

\section{Ukuhlonipha}

One of the methods of reducing dissonance is to acquire new information that outweighs the dissonant beliefs. The researchers believe that in teacher training, it is very important to have a space where we teach that we cannot separate culture and language, and that culture cannot stop you from using a language as required, meaning married women in the field of education should be made aware of this new knowledge - that there is no "hlonipha language" in the classroom (language of avoidance), and there should be no avoidance of words because of culture in the classroom. Individuals can change one or more of the attitudes, behaviour, beliefs and so on to make the relationship between the two elements a consonant one. What does this mean about teacher training? It means there must be strategies to transform attitudes and beliefs that can be barriers in the classroom such as codeswitching

\section{References}

[1] Baker, M. (2011). In other words: A course book on translation. London: Routledge.

[2] Bongela, Knobel S. (2001). Isihlonipha among the ama Xhosa, PhD thesis, University of South. 
[3] Carton, B. (2000). Blood from your children: The colonial origins of generational conflict in South Africa. Pietermaritzburg: University of Natal Press.

[4] Department of Basic Education (DBE) (2011). National Curriculum Statement Grades R-12 Curriculum and Assessment Policy Statement (CAPS). Pretoria: Department of Education.

[5] Desai, Z. (2013). Local languages: Good for the informal marketplace but not for the formal classroom? Education as Change, 17(2), 193-207.

[6] Diaz, C. (1992). Multilingual education for the $21^{\text {st }}$ century. Washington: National Educational Association.

[7] Dlodlo, T. S. (1999). Science nomenclature in Africa: Physics in Nguni. Journal of Research in Science Teaching, 36(3), 321-331.

[8] Ellis, H. (1999). Function of taboos, their vital role in community and how they bolster the discipline of compassion. https:wwwbrainpickings.org- Accessed on 15/07/2016.

[9] Festinger, L. (1957). A Theory of cognitive dissonance. Stanford, CA: Stanford University Press.

[10] Gambier, Y. (2007). Doubts and Directions in Translation Studies, Leiden, the Netherlands: John Benjamins.

[11] Gillman, B. (2000). The research interview. London: Continuum.

[12] Gomm, R. (2004). Social Research Methodology. A critical introduction.

[13] Glaser, B., \& Strauss, A. (2009). The discovery of grounded theory. Mill Valley, CA: Transactions Publications.

[14] Gxilishe, D. S. (1996). "The dilemma of dialect in the classroom: a case for isiXhosa" in PER LINGUAM, 12 (1): 110 .

[15] Jadezweni, M. \& Mfazwe-Mojapelo, L. (2015). Achieving Public Acceptability of Taboo Words Translated into isiXhosa. Focus address delivered at Cape Peninsula University of Technology at the $18^{\text {th }}$ African Languages Association of Southern Africa (ALASA), 24-25 June 2015.

[16] Larson, M. (1984). Meaning-based translation: A Guide to Cross-Language Equivalence. New York: University press of America.

[17] Lemke, J. L. (2005). Textual politics: Discourse and social dynamics. Oxford: Taylor \& Francis.

[18] Liu, F., \& Maitlis, S. (2010). Nonparticipant Observation. In Albert J. Mills, G. Durepos, \& E. Wiebe (Eds.), Encyclopedia of Case Study Research. (pp. 610-612). Thousand Oaks, CA: SAGE Publications. Retrieved from: http://srmo.sagepub.com/view/encyc-of-case-studyresearch/n229.xml.

[19] Madiba, M. (2012). Language and academic achievement: Perspectives on the potential role of indigenous African languages as a lingua academica. Per Linguam, 28(2), 15-27.
[20] Mbekwa, M., \& Nomlomo, V. (2012). Voices from the Classroom. In D. P. Napier and S. Mahjanovich (Eds) Education, dominance and identity (pp. 133-149). Rotterdam: Sense Publishers.

[21] Mchunu, M. R. (2016). Zulu fathers and their sons: sexual taboos, respect and their relationship to the HIV/AIDS pandemic. University of KwaZulu-Natal: Durban. Unpublished.

[22] Moletsane, R. (2012). Postgraduate educational research on violence, gender and HIV/AIDS in and around schools (19952004), South African Journal of Higher. 25 (2), 287-300.

[23] Mouton, J. (2011). How to succeed in your Master's and Doctoral studies: A South African guide and resource book. Pretoria: Van Schaik.

[24] Msimanga, A., \& Lelliott, A. (2014). Talking Science in Multilingual Contexts in South Africa: Possibilities and challenges for engagement in learners home languages in high school classrooms. International Journal of Science Education, 36(7), p. 1159-1183.

[25] Newmark, P. (1988) A Textbook of Translation. Hertfordshire: Prentice Hall.

[26] Niehaus D. J. H. et al. (2004). A Culture-Bound Syndrome 'Amafufunyana' and a Culture-Specific Event 'Ukuthwasa': Differentiated by a Family History of Schizophrenia and other Psychiatric Disorders. Psychopathology, 37(2), 59-63.

[27] Nkoane MM (2010). Listening to the voices of the voiceless: A critical consciousness for academic industrial complex. South African Journal of Higher Education, 24(3):317-341.

[28] Prah, K. (2003). Going native: Language of instruction in education, development and African emancipation. In B. Brock-Utne, Z. Desai and M. Qorro (Eds.), Language of instruction in Tanzania and South Africa (LOITSA) (14-34). Dar es Salaam: E \& D Limited.

[29] Ritchie, J. and J. Lewis (2003). Qualitative research practice: a guide for social science students and researchers.

[30] Sapir, E. (1956). Culture, Language and Personality. Los Angeles: University of California Press.

[31] Shuttleworth, M. and M. Cowie, Eds. (1997). Dictionary of Translation Studies. Manchester: St Jerome.

[32] Spofana, D. (2010). The importance of dialect awareness in a classroom context with special reference to isiXhosa. Focus address delivered at the Interim Conference African Languages Association of Southern Africa (ALASA, University of Botswana, Botswana $21^{\text {st }}$ to $23^{\text {rd }}$ July 2010 .

[33] UNESCO. (2003). Education in a Multilingual World. Paris, UNESCO. http://unesdoc.unesco.org/images/0012/001297/129728e.pdf.

[34] Venuti, L. (2008). The Translator's Invisibility. A History of Translation. London: Routledge.

[35] McMillan, H. J. \& Schumacher, S. (1993). Research in education. A conceptual introduction. New York: Harper Collins. 